\title{
Population Dynamics of the White Spotted Rabbitfish (Siganus canaliculatus Park, 1797) in Panguil Bay, Philippines
}

\author{
Alejandro M. Gonzaga, Jr. \\ Assistant Professor IV, College of Fisheries, Mindanao State University \\ Marawi City, Lanao del Sur, 9700, Philippines
}

\begin{abstract}
The white spotted rabbitfish (Siganus canaliculatus Park, 1797) is a commercially important commodity occurring in the northern coast and southern coast of Panguil Bay. This fish was reported to be caught by fishing gears like filter net, fish corral, bottom set gill net, stationary lift net, motorized scissors net, and spear. To understand the population dynamics and associated status of white spotted rabbitfish in Panguil Bay, the growth, mortality, exploitation and recruitment pattern were determined from June 2002 to May 2003. A total of 1,513 samples of white spotted rabbitfish were collected from the four sampling stations established in Panguil Bay. Growth was estimated using the FiSAT II and the estimated parameters were $L \infty=33.20 \mathrm{~cm}$ and $K=0.54 \mathrm{yr}-1$. Total, natural and fishing instantaneous rate of mortality values were $\mathrm{Z}=3.80 \mathrm{yr}^{-1}, \mathrm{M}=1.18 \mathrm{yr}^{-1}, \mathrm{~F}=$ $2.62 \mathrm{yr}^{-1}$ and the exploitation rate value was $\mathrm{E}=0.69 \mathrm{yr}^{-}$

1. Projected recruitment pattern of $S$. canaliculatus suggests that this species spawns all year round. Based on the results, $S$. canaliculatus caught by fish corral in Panguil Bay from June 2002 to May 2003 was overexploited and that management strategies of this resource must be promulgated and implemented to address the depleting fishery.
\end{abstract}

Keywords:- Growth, mortality, exploitation rates, recruitment, population dynamics, White Spotted Rabbitfish, Siganus canaliculatus Park, 1797, Panguil Bay.

\section{INTRODUCTION}

The white-spotted rabbitfish (Siganus canaliculatus Park, 1797) belongs to the Family Siganidae. This species is almost all marine and is widely distributed throughout the world. It thrives all over the Indo-West Pacific regions: Persian Gulf, Pakistan, Sri Lanka, Burma, Thailand, Malaysia, Indonesia, Papua New Guinea, Cambodia, Viet Nam, South China, Taiwan [43], Gulf of Oman [32], India [19], [41], [22], Philippines [14], [23], [35], [38], Great Barrier Reef of Western Australia [33]. It is also distributed in Japan [15], [20], Palau and Yap, Micronesia [25], [3], [13] Hong Kong [44], [30] and in the southern Arabian Gulf [11].

In the Philippines, $S$. canaliculatus is geographically distributed in Panguil Bay [14], Southern Negros [23], Northwestern Sulu Sea, Southern Sulu Sea, Samar Sea, Bohol Strait, San Miguel Bay, Davao Gulf,
Visayan Sea, Lingayen Gulf and in Lagonoy Gulf [35]. S. canaliculatus inhabits inshore and reef areas dominated by algae. It is also known to occur in estuaries and in large lagoons where there are algae-rubble habitats. This species is mainly common on rocky substrates. It can tolerate in turbid waters occurring within the vicinity of river mouths especially around seagrass beds. It also occurs several kilometers offshore in deep clear waters. Juveniles of $S$. canaliculatus form very large schools in shallow bays and coral reef flats. School size of $S$. canaliculatus reduces with size, with adults occurring in groups of 20 individuals or so [43].

In Panguil Bay, studies on $S$. canaliculatus inhabiting the bay were very few. Only the work on the taxonomic identification of different fish species of the bay are available [14], [43]. Panguil Bay is one of the most important shallow water fishing grounds in all of Mindanao, Southern Philippines. The bay is an important trading link between the provinces of Lanao del Norte, Zamboanga del Sur and Misamis Occidental and, indirectly, the combined coastal population of 451,362 people is affected by the stability of the coastal environment [2].

The bay is the source of some of the most valuable species of shrimps and crustaceans. The bay has supported superior quality of Penaeus monodon and the mud crab, Scylla serrata which had spawned a backyard industry for crab fattening. The rivers and tributaries of the inner bay are known to host a mature population of the giant freshwater prawn, Macrobrachium rosenbeergii, as well as mullets, eels and spadefish [2]. Moreover, the bay is home to various important finfish species like gobies, anchovies, mullets, pony fishes, blue crabs, therapons, carangids, lantern fishes, and hairtails. In addition, there are two species of commercially important mollusks, Modiolus metcalfei and M. elongates and at least three species of seaweeds that provide alternative sources of income to fishermen [2]. Likewise, the bay supports a fishery consisting of different species including that of $S$. canaliculatus [14], [43].

Fishing is an important source of livelihood among the population living in the coastal barangays of Panguil Bay. Fishing in the bay is artisanal and subsistence in nature. Fishermen in the coastal barangays used different types of fishing gears in exploiting the pelagic stocks of the bay. Filter net was the most abundant gear type in the area 
with 1,600 units, followed by fish corral with 683 units, bottom set gill net with 300 units, stationary lift net with 60 units and the motorized scissor net with 12 units [2].

In Panguil Bay, persistent violations of fishery laws are commonplace. From 1990 to 1991, the law enforcement of the Panguil Bay Development Council confiscated and destroyed some 1,600 filter nets, apprehended more than 60 violators, seized some 30 scissor nets and uprooted more than 200 net posts in the bay. Despite these efforts, fishermen continued to circumvent the laws. The popular fish corrals, a legitimate gear in the Philippines, have been modified to include double netting of legal mesh size but which stretch to almost nil when oriented towards the current, in the process straining everything but the water [2].

The capacity of fisheries resources to sustain such exploitation is a function of demographic characteristics such as growth and mortality rates of the respective fish species populations. Estimation of these parameters is a paramount measure to understand the population dynamics and associated status of exploited species. Furthermore, these will provide the key reference points required for the development of rational fisheries management regimes [11].

This study aims to determine the population dynamics of white spotted rabbitfish in Panguil Bay. Specifically, this study seeks to estimate the population parameters such as the asymptotic length $(\mathrm{L} \infty)$, growth coefficient $(\mathrm{K})$ and the total, natural and fishing mortalities ( $\mathrm{Z}, \mathrm{M}$ and $\mathrm{F})$, and describe the state of exploitation and recruitment pattern.

\section{MATERIALS AND METHODS}

\section{Study area}

Panguil Bay lies in $7^{\circ} 56^{\prime}-8^{\circ} 04^{\prime} \mathrm{N}, 1^{\circ} 3^{\circ} 36^{\prime}-$ $123^{\circ} 46^{\prime} \mathrm{E}$. It is in the southern island of Mindanao and bordered by the provinces of Lanao del Norte in the east and Zamboanga del Sur and Misamis Occidental in the West. Four sampling stations were established in Panguil Bay. The four stations (S) monitored from catches of $S$. canaliculatus were San Antonio, Gango, Ozamiz City (S1), Malaubang, Ozamiz City (S2), Maigo, Lanao del Norte (S3) and Tubod, Lanao del Norte (S4) (Fig. 1). These respective stations were landing areas of various fishery resource caught in Panguil Bay.

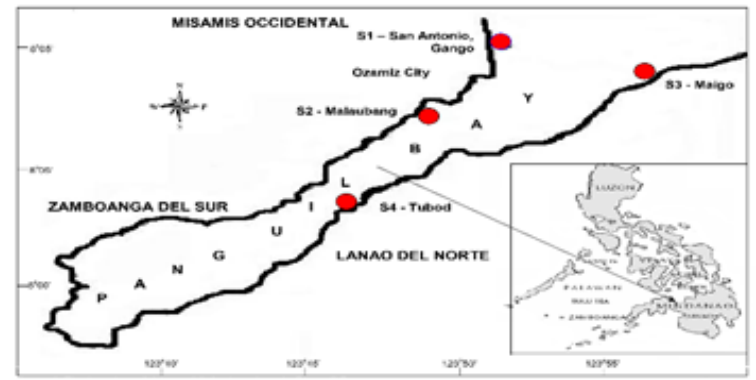

Fig 1:- The location of the established stations in Panguil Bay.

\section{$>$ Data Gathering}

Sampling was done twice a month. A total of 1,513 samples of $S$. canaliculatus were collected from fish corral catches (Figs. 2-4) from each station from June 2002 to May 2003. From the landing site, the samples were stored in styrofoam box preserved at very low temperature. After collecting samples from each station, the same were then brought at the MSU-IFRD laboratory for length-weight determinations. At the laboratory, the total length (TL) of each sample $S$. canaliculatus was measured to the nearest $\mathrm{cm}$ from the tip of the snout to tip of the upper caudal lobe using a graduated measuring board. Whole wet weight (WW) of each sample was measured to the nearest $0.1 \mathrm{~g}$ using a Nagata weighing scale [19].

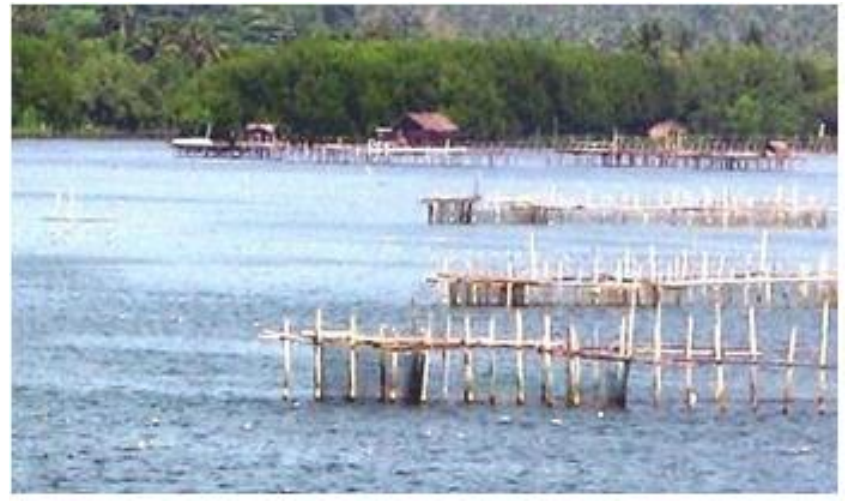

Fig 2:- Fish corral in Malaubang, Ozamiz City.

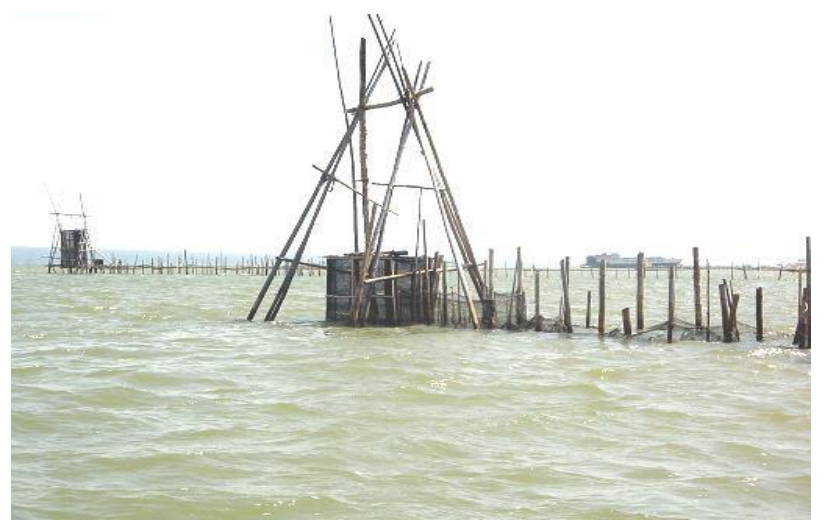

Fig 3:- Fish corral in Tubod, Lanao del Norte.

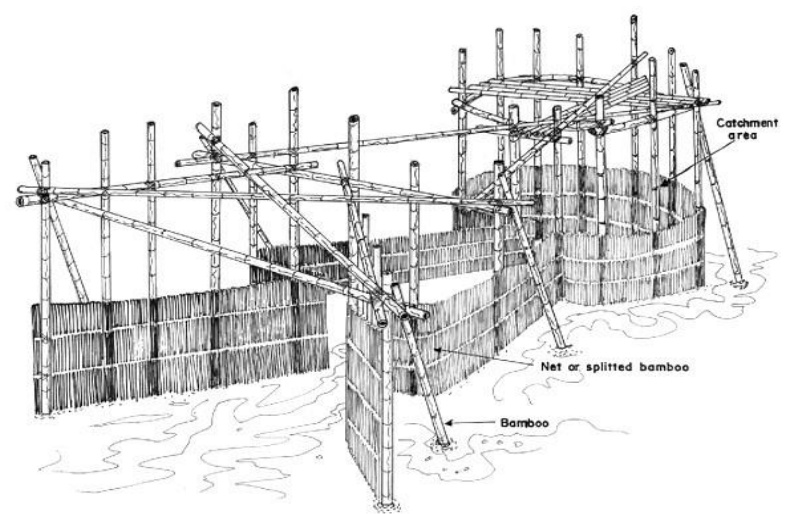

Fig 4:- The operational view of a simple type of fish corral. 


\section{$>$ Population parameters estimation \\ - Growth}

Siganus canaliculatus growth parameters $\mathrm{L}_{\infty}$ and $\mathrm{K}$ of the Von Bertalanffy equation for growth in length were estimated using the ELEFAN I available in the FAOICLARM Stock Assessment Tools (FiSAT) software [8]. The method restructures the length- frequency data and the growth curve which have the best fit to the peaks is identified. The input data used were the length-frequency data of $S$. canaliculatus caught by fish corral in Panguil Bay from June 2002 to May 2003.

The ELEFAN I (Electronic Length Frequency Analysis) program was developed by [28]. The idea behind the method is to split a composite distribution into peaks and troughs, and to find the best growth curve passing through the maximum number of peaks and avoiding troughs as far as possible. Goodness of fit is assessed by the ratio of ESP/ASP, where ESP (Explained Sum of Peaks) is the number of peaks accumulated by a growth curve while ASP (Available Sum of Peaks) is the highest number of peaks that the best growth curve can accumulate for a given value of length-frequency data.

\section{- Mortality}

\section{$\checkmark$ Total mortality (Z)}

The annual instantaneous rate of total mortality $(\mathrm{Z})$ was derived from the length converted catch-curve analysis utilizing the ELEFAN II routine [8]. Pooled length frequency samples were converted into relative age frequency distributions by means of the inverse of the von Bertalanffy function for the species. The natural logarithm of the number of fish in each group divided by the change in relative age was plotted against the relative age. The annual instantaneous rate of total mortality was estimated from the slope of the best fit line through the descending data points using least-squares linear regression. Initial ascending points representing fish not fully recruited to the fishery or too small to be vulnerable to the gear were excluded from the regression.

\section{$\checkmark \quad$ Natural mortality $(M)$}

Estimates of annual natural mortality rate (M) was obtained using the empirical formula derived by [29]:

$\log \mathrm{M}=-0.0066-0.279 \log \mathrm{L}_{\infty}+0.6453 \log \mathrm{K}+0.4634$ $\log \mathrm{T}$

Where:

$K$ and $L_{\infty}$ are derived from the von Bertalanffy growth function

$T$ is the annual mean temperature of $29^{\circ} \mathrm{C}$

\section{$\checkmark$ Fishing mortality $(F)$}

The annual estimates of fishing mortality $(\mathrm{F})$ was calculated by subtracting the natural mortality $(\mathrm{M})$ from the total mortality $\mathrm{Z}(\mathrm{F}=\mathrm{Z}-\mathrm{M})$.

\section{$\checkmark$ Exploitation rate $(E)$}

The existing exploitation rate $(\mathrm{E})$ was calculated as the proportion of the fishing mortality relative to the total mortality $(\mathrm{E}=\mathrm{F} / \mathrm{Z})$.

\section{$\checkmark$ Recruitment pattern}

The ELEFAN software package also provides a description of the recruitment pattern using the final growth parameters obtained. The recruitment pattern was obtained by projecting a set of length-frequency data backward onto a one-year time axis [18].

\section{RESULTS AND DISCUSSION}

\section{$>$ Growth parameters}

The growth curves fitted by ELEFAN I estimated different values of asymptotic length $L_{\infty}$ and growth coefficient $\mathrm{K}$ for the length-frequency data of $S$. canaliculatus with a $1 \mathrm{~cm}$ class interval. The best estimated value obtained for the parameter $\mathrm{L}_{\infty}$ was $33.20 \mathrm{~cm}$ and for $\mathrm{K}$ was $0.54 \mathrm{yr}^{-1}$ from June 2002-May 2003. Given the above estimates, the peaks in the length-frequency data were more clearly outlined and this enabled a good fit of the growth curves to be obtained. The parameters obtained were later utilized as an input data for the subsequent estimation of the mortality and exploitation rate and for the derivation of the recruitment pattern. The length-frequency data and superimposed growth curve for S. canaliculatus showed that peaks being hit by the growth curve from the months of June, July, August, September, November, December 2002 and January 2003 were sample of bigger sizes (Fig. 5). Peaks from October 2002 to May 2003 hit by the growth curve were samples dominated by smaller length groups. However, peaks which were not hit by the growth curve were left unexplained. This may be possibly caused by the heterogeneity of the sizes of the samples collected.

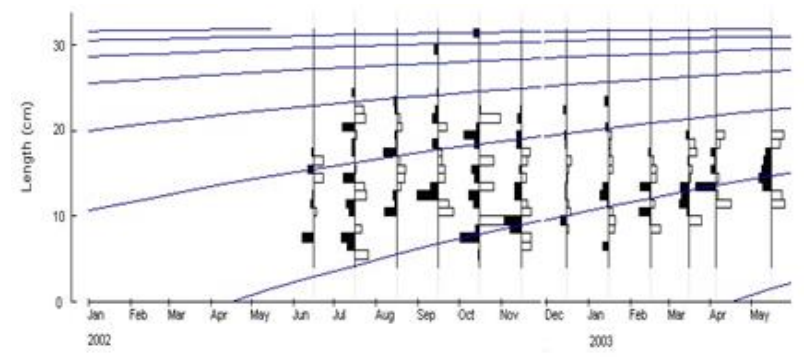

Fig 5:- Restructured length-frequency data (ELEFAN I) and superimposed growth curve of Siganus canaliculatus Park using a class interval of $1 \mathrm{~cm}$. Estimated values are $\mathrm{L}_{\infty}=$ $33.20 \mathrm{~cm}, \mathrm{~K}=0.54 \mathrm{y}^{-1}$ with starting sample $(\mathrm{SS})=5$ and starting length $(\mathrm{SL})=31.45 \mathrm{~cm}$.

In the Rayong Gulf of Thailand, $S$. canaliculatus was estimated to have an $\mathrm{L}_{\infty}$ and $\mathrm{K}$ values of $28.1 \mathrm{~cm}$ and $2.0 \mathrm{yr}^{-1}$, respectively [43]. In Hong Kong, this species had estimated $\mathrm{L}_{\infty}=28.40 \mathrm{~cm}$ and $\mathrm{K}=0.43 \mathrm{yr}^{-1}$ [30], in the southern Arabian Gulf, $\mathrm{L}_{\infty}=24.8 \mathrm{~cm}$ and $\mathrm{K}=1.0 \mathrm{yr}^{-1}[11]$, and in Lagonoy Gulf of the Philippines, $\mathrm{L}_{\infty}=28.5 \mathrm{~cm}$ and $\mathrm{K}=$ $0.58 \mathrm{yr}^{-1}$ [38]. The estimated value of $\mathrm{L}_{\infty}$ for $S$. canaliculatus in Panguil Bay was higher compared to those obtained by [43], [30], [11] and [38]. The growth coefficient $\mathrm{K}$ value for $S$. canaliculatus estimated in Panguil Bay was lower than those estimates of [43], [11] and [38]. However, the estimated $\mathrm{K}$ was higher than the result of [30]. The high rate at which size is attained is a 
manifestation of the general feature of the growth characteristics for members of this species and is one of the reasons for their mariculture potential [21]. Siganus canaliculatus grows to a mean standard length of $8 \mathrm{~cm}$ in about 3 months, $10 \mathrm{~cm}$ in about 4 months and $14 \mathrm{~cm}$ in 7-8 months [23].

This results obtained in Panguil Bay varies with that of [43], [30], [11], and with [38]. The longer asymptotic length $\mathrm{L}_{\infty}$ value, however, had lower growth coefficient $\mathrm{K}$ value obtained for S. canaliculatus which was typical value for short-lived tropical fishes with fast biomass turn-over [27] This suggests that individuals of $S$. canaliculatus in Panguil Bay had a long, thin and slender body or it had an intermediate size similar to those found in Lagonoy Gulf. The observation made from the previous length-weight relationship analysis showed that this species had a negative allometric growth. Moreover, the variation in the estimation of the growth parameters of the fish was attributed to the prevailing environmental condition, availability of food, water temperature fluctuation, water current [11] and season [39]. In the southern Arabian Gulf, the deposition of growth increments observed follows the general pattern and formations of the opaque band appeared to be closely associated with the increase in seawater temperature [11].

Other factors that affect the variations in the estimation of growth parameters were attributed to the application of the methods that were used in analyzing the length-frequency data from the respective studies (i.e., Shepherd's and Powell-Wetheral). The variation of the estimates was also caused by the manipulation of the ELEFAN routine, that is in selecting the starting sampling points. In addition, there was a wide range of possible combinations for the parameters $L_{\infty}$ and $K$ of the von Bertalanffy growth function to select with given by similar score functions $(\mathrm{Rn})$ for the non-parametric scoring using ELEFAN I [10].

\section{$>$ Mortality and exploitation}

The annual instantaneous rate of total mortality $(\mathrm{Z})$ derived from the length converted catch curve was $3.80 \mathrm{yr}^{-1}$ (Fig. 6). Annual instantaneous rate of natural mortality (M) was estimated at $1.18 \mathrm{yr}^{-1}$ after using the empirical formula derived by [29]. The annual instantaneous rate of fishing mortality (F) was estimated at $2.62 \mathrm{yr}^{-1}$. The estimated exploitation rate (E) was $0.69 \mathrm{yr}^{-1}$. The correlation coefficient $\mathrm{R}^{2}$ value of 0.99 obtained in the length converted catch curve analysis suggests strong relationship between points selected in the catch curve.

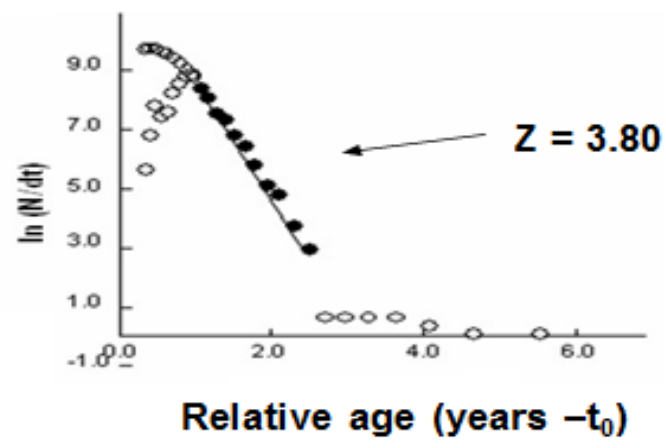

Fig 6:- Length-converted catch curve of Siganus canaliculatus Park caught by fish corral in Panguil Bay from June 2002 to May 2003.

The length converted catch curve method was used in estimating the annual instantaneous rate of total mortality (Z). It is based on the assumption that all of the relative age groups used in the analyses were equally vulnerable to the fishing gear and equally abundant at recruitment. Violations of these assumptions may introduce errors [10].

A reported total mortality of $1.51 \mathrm{yr}^{-1}$, natural mortality of $0.66 \mathrm{yr}^{-1}$ and a fishing mortality of $0.85 \mathrm{yr}^{-1}$ for S. canaliculatus was reported in the Southern Arabian Gulf [11]. In Hong Kong, [33] had reported a total mortality of $4.17 \mathrm{yr}^{-1}$ for this species. In Lagonoy Gulf of the Philippines, this species was reported to have a total mortality of $3.0 \mathrm{yr}^{-1}$, natural mortality of $1.29 \mathrm{yr}^{-1}$ and a fishing mortality $1.71 \mathrm{yr}^{-1}$. The derived value of total mortality from this study was higher compared to those of [11] and [38].

The higher value of total mortality $(\mathrm{Z})$ obtained is an indicative of the greater fishing mortality as effected by fishing pressure exerted to the individuals of $S$. canaliculatus in Panguil Bay. Siganus canaliculatus mostly caught by fish corral were of smaller length groups. The absence of larger individuals of $S$. canaliculatus in the catch suggests that the larger length groups may have been affected by fishing pressure of other fishing gears commonly used in the area like the underground filter nets and bottom set gill nets. It was observed that juveniles and mature individuals co-occurred. Their simultaneous cooccurrence was attributed to the spawning time among adults. This collective behaviour of the fish renders both the young and adults simultaneously vulnerable to high exploitation [38]. Such value for Z, however, signifies very low annual survival rates, typical for most short-lived tropical fish species but relatively imply a fast turnover ratio [37]. It is also possible that the size and age compositions and associated estimates of $\mathrm{Z}$ may have been biased by ontogenetic or spawning migrations [11]. The natural mortality (M) was lower compared to those obtained by [38]. However, the fishing mortality (F) was higher than the rate obtained by [38] and [11]. 
In the Gulf of Lagonoy, fishers exploited the immature fish by capitalizing on their indigenous knowledge of siganid settlement [38]. The "runs" or migration of juveniles toward the coast [43], [38], which fishers observed through the years, determine the timing of fishing activities. Bagnets and seine nets were operated on the same day juveniles occurred, particularly during new moons.

In Panguil Bay, fishing is an important source of livelihood among the population living in the coastal barangays. In 1980, a total about 4,000 persons comprised the fishing population in the coastal area, either part time or full time fishermen. Moreover, the number of fishing craft was reported to increase from 2,033 in 1984 to 5,609 in 1991 [2]

The high estimated exploitation rate was a result of the high levels of annual instantaneous rate of both fishing and total mortality. The fish stock to be optimally exploited, fishing mortality $(\mathrm{F})$ should be equal to natural mortality $(\mathrm{M})$, or $\mathrm{F}_{\text {optimum }} \approx \mathrm{M}$, which corresponds to $\mathrm{E}_{\text {optimum }} \approx 0.5$ (Pauly, 1984). The specified precautionary target $\left(\mathrm{F}_{\text {optimum }}=0.5 * \mathrm{M}\right)$ and limit $\left(\mathrm{F}_{\text {limit }}=2 / 3 * \mathrm{M}\right)$ values were considered to be appropriate biological reference points, in particular given current management objectives which aimed at stock re-building and resource conservation (Grandcourt, et al., 2007). The fishing mortality (F) of 2.62 $\mathrm{yr}^{-1}$ was greater than both the target $\left(\mathrm{F}_{\text {optimum }} \approx 0.59\right.$ year $\left.{ }^{-1}\right)$ and limit $\left(\mathrm{F}_{\text {limit }}=0.79 \mathrm{yr}^{-1}\right)$ biological reference points in Panguil Bay. The results indicate that there is overfishing of $S$. canaliculatus in Panguil Bay.

\section{Recruitment}

In Panguil Bay, there was only one pulse of annual recruitment for S. canaliculatus (Fig. 7). This suggests that recruitment of new stock into the fishery is all year round.

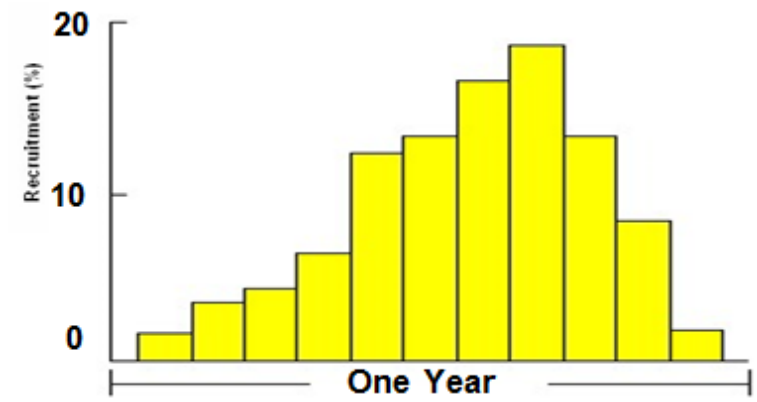

Fig 7:- Recruitment pattern of Siganus canaliculatus Park caught by fish corral in Panguil Bay from June 2002 to May 2003.

The recruitment pattern of new stock of $S$. canaliculatus in Panguil Bay is all year round. This recruitment pattern agrees to the observation made on the gonadal maturity stage of $S$. canaliculatus wherein spawning is not only restricted to a definite period of time, particularly in Panguil Bay. This result also conformed with the findings for the same species in the Western Indian Ocean Waters [41].

\section{CONCLUSION}

The best growth parameters estimated for $S$. canaliculatus were $\mathrm{L}_{\infty}=33.20 \mathrm{~cm}$ and $\mathrm{K}=0.54 \mathrm{yr}^{-1}$. The annual instantaneous rate of total mortality $(\mathrm{Z})$ derived from the length converted catch curve was $3.80 \mathrm{yr}^{-1}$. Annual instantaneous rate of natural mortality (M) was estimated at $1.18 \mathrm{yr}^{-1}$. The annual instantaneous rate of fishing mortality $(\mathrm{F})$ was estimated at $2.62 \mathrm{yr}^{-1}$.

The higher value of total mortality $(\mathrm{Z})$ obtained was indicative of the greater fishing mortality as effected by fishing pressure exerted to the individuals of $S$. canaliculatus in Panguil Bay. S. canaliculatus mostly caught by fish corral were samples belonging to the smaller length groups. The absence of larger $S$. canaliculatus in the catch may suggest that the larger length groups may have been affected by fishing pressure of other fishing gears like the underground filter nets and bottom set gill net commonly used in the area.

The estimated exploitation rate (E) of $0.69 \mathrm{yr}^{-1}$ exceeded the $\mathrm{E}_{\text {optimum }}=0.5$ was a result of the high levels of annual instantaneous rate of both fishing and total mortality. The fishing mortality $(\mathrm{F})$ of $2.62 \mathrm{yr}^{-1}$ was greater than both the target $\left(\mathrm{F}_{\text {optimum }} \approx 0.59 \mathrm{yr}^{-1}\right)$ and limit $\left(\mathrm{F}_{\text {limit }}=0.79 \mathrm{yr}^{-1}\right)$ biological reference points. This study revealed that white spotted rabbitfish (Siganus canaliculatus Park, 1797) in Panguil Bay are overexploited. Thus, fishery resource management interventions and strategies for this species must be promulgated and implemented.

The recruitment pattern derived for $S$. canaliculatus in Panguil Bay showed that there was only one pulse of annual recruitment. This demonstrates that recruitment of new stock of $S$. canaliculatus into the fishery is all year round.

\section{REFERENCES}

[1]. Balon, E. K. 1984. Patterns in the evolution of reproductive styles in fishes. In: G. W. Potts and R. J. Wotton (eds.), pp103-117. Fish Reproduction, Strategies, Tactics. Academy Press, London.

[2]. Bengson, B. Q. and B. S. Francisco. 1992. FAO Japan expert consultation on the development of community based coastal fishery management systems for Asia and the Pacific. FAO Fish. Rep. No. 474(1):103-116.

[3]. Bryan, P. G., B. B. Madraisau, and J. P. Mc Vey. 1975. Hormone induced and natural spawning of captive Siganus canaliculatus (Pisces: Siganidae) year round. Micronesica 11(2): 199204.

[4]. Bwathondi, P. O. J. 1982. Preliminary investigations on rabbitfish, Siganus canaliculatus cultivation in Tanzania. Aqua. 27(3): 205-210.

[5]. Chan, S. M., W. X. Wang, and I. H. Ni. 2003. The uptake of $\mathrm{Cd}, \mathrm{Cr}$, and $\mathrm{Zn}$ by the macroalga Enteromorpha crinita and subsequent transfer to the 
marine rabbitfish, Siganus canaliculatus. Arch. Environ. Contam. Toxicol. 44(33):298-306.

[6]. El-Sayed, A.M., K. A. Mostafa, J. S. Al-mohammad, A. El-dehaimi, and M. Kayid. 1995. Effects of stocking density and feeding levels on growth rates and feed utilization of rabbitfish Siganus canaliculatus. J. World Aqua. Soc. 26(2):212-216.

[7]. Fox, R. J. and D. R. Bellwood. 2008. Remote video bioassays reveal the potential feeding impact of the rabbitfish Siganus canaliculatus (f: Siganidae) on an inner-shelf of the Great Barrier Reef. Coral Reefs 27:605-615.

[8]. Gayanilo, F. P., P. Sparre, and D. Pauly. 1994. FAO-ICLARM stock assessment tools (FiSAT). FAO, Rome.

[9]. Gomez, K. and A. Gomez. 1976. Statistical procedures for agricultural research. John Wiley and Sons. New York. 23-35.

[10]. Grandcourt, E. T., F. Francis, A. Al Shamsi, K. Al Ali, and S. Al Ali. 2003. Stock assessment and biology of key species in the demersal fisheries of the Emirate of Abu Dhabi. Marine Environemental Research Centre, Environmental Research and Wildlife Development Agency.

[11]. Grandcourt, E. T. Al Abdessalaam, F. Francis, and A. Al Shamsi. 2007. Population biology and assessment of the white-spotted spinefoot, Siganus canaliculatus (Park, 1797), in the southern Arabian Gulf. J. Apll. Ichthyo. 23:53-59.

[12]. Gulland, J. A. 1969. Manual of methods of fish stock assessment. Part I. Fish population analysis. FAO Man. Fish. Sci. 154.

[13]. Hasse, J. J., B. B. Madraisau, and J. P. McVey. 1977. Some aspects of the life history of Siganus canaliculatus (Park) (Pisces: Siganidae) in Palau. Micronesica 13:297-312.

[14]. Herre, A. W. 1959. Marine fishes in Phillipine lakes and rivers. Phil. J. 87:65-88.

[15]. Hoque, M. M., A. Takemura, and K. Takano. 1998. Annual changes in oocyte development and serum vitellogenin level in the rabbitfish, Siganus canaliculatus (Park), in Okinawa, southern Japan. Fish. Sci. 64:45-52.

[16]. Hoque M. M., A. Takemura, M. Matsuyama, S. Matsuura, and K. Takano. 1999. Lunar spawning in Siganus canaliculatus. J. Fish Bio. 55(6):1213-1222.

[17]. Hwang, H. K., C. B. Park, Y. J. Kang, J. H. Lee, S. Rho and Y. D. Lee. 2004. Gonadal development and reproductive cycle of the rabbitfish (Siganus canaliculatus) J. Korean Fish. Soc. 37(5):393-399.

[18]. Ingles, J. and D. Pauly. 1981. Aspects of the growth and natural mortality of exploited coral reef fishes. The reef and man. Proceedings of the fourth international coral reef symposium. Marine Science Center, University of the Philippines, Quezon City, Philippines. 1:88-98.

[19]. Jayasankar, P. 1990. Some aspects of biology of the white-spotted spine-foot, Siganus canaliculatus Park 1797 from the gulf of Mannar. Indian J. Fish. 37(1):9-14.
[20]. Kiyoaki, K., F. Motonaga, and K. Motofumi. 1999. Settlement of white-spotted spinefoot, Siganus canaliculatus (Pisces: Siganidae), in the coastal waters off Okinawa Island, Japan. The Jap. Soc. of Fish. Sci. 65(1):19-25.

[21]. Lam, T. J. 1974. Siganids: Their biology and mariculture potential. Aqua. 3(4):325-354.

[22]. Lam, T. J. and C. L. Soh. 1975. Effect of photoperiod on gonadal maturation in the rabbitfish, Siganus canaliculatus Park 1797. J. Aqua. 5(4):407410.

[23]. Laviña, E. M. and A. C. Alcala. 1974. Ecological studies of Philippine Siganid fishes in southern Negros. Silliman J. 21:191-120.

[24]. Manacop, P. R. 1937. The artificial fertilization of danggit, Amphacanthus oramin (Bloch and Schneider). Phil. J. Sci. 62:229-237.

[25]. May, R. C., D. Popper, and J. P. Mc Vey. 1974. Rearing and larval development of Siganus canaliculatus Park (Piseces: Siganidae). Micronesica 10(2):285-298.

[26]. Motoh, H. 1980. Fishing gear for prawn and shrimp used in the Philippines today. SEAFDEC Technical Report No. 5. SEAFDEC, Ilo-ilo City, Philippines.

[27]. Pauly, D. 1980. On the interrelationships between natural mortality, growth parameters and mean environmental temperature in 175 stocks. J. cons. Mt. Explor. Mer. 39(3):175-192.

[28]. Pauly, D. and N. David. 1981. ELEFAN I, a basic program for the objective extraction of growth parameters from length-frequency data. Meeresforch 28(4): 205-211.

[29]. Pauly, D. 1984. Fish population dynamics in tropical waters: A manual for use with programmable calculators. International Center for Living Aquatic Resources Management ICLARM. Manila, Philippines.

[30]. Pauly, D., T. J. Pitcher, R. Watson, and A. Courtney. 1998. Assessment of Hong Kong's inshore fishery resources. Fisheries Center, University of British Columbia.

[31]. Rahman, Md. S., B. Kim, A. Takemura, C. Park, and Y. Lee. 2004. Influence of light-dark and lunar cycles on the ocular melatonin rhythms in the seagrass rabbitfish, a lunar synchronized spawner. $J$. Pin. Res. 37(2):122-128.

[32]. Randall, J. E. 1995. Coastal fishes of Oman. University of Hawaii Press. Honolulu, HI. 439.

[33]. Randall, J. E., G. R. Allen, and R. C. Steene. 1997. Fishes of the Great Barrier Reef and Coral Sea. University of Hawaii Press. Honolulu, HI. 507.

[34]. Ricker, W. R. 1975. Computation and interpretation of biological statistics of fish population. Bull. Fish. Res. Bd. Canada 191: 382.

[35]. Rosario, W. M. 1974. Observation on the rate of growth of siganid fry "padas" confined in concrete tanks. The Phil. J. Fish. 12(1-2). 
[36]. Saito, H., R. Yamashiro, C. Alasalvar, and T. Konno. 1999. Influence of diet on fatty acids of three subtropical fish, subfamily caesioninae (Caesio diagramma and C. tile) and family Siganidae (Siganus canaliculatus). J. Lipids 34(10):1073-1082.

[37]. Silvestre, G. I. 1985. Preliminary analysis of the growth, maturity and yield-per-recruit of ten trawlcaught species from the Samar Sea, Philippines. Phil. J. Fish. 7(1):13-33.

[38]. Soliman, V. S., R. U. Bobiles, and K. Yamaoka. 2009. Overfishing of three siganid species Family: siganidae) in Lagonoy Gulf, Philippines. Kuroshio Sci. 2:145-150.

[39]. Ursin, E. 1963. On the incorporation of temperature in the Von Bertalanffy growth equation. Medd. Dan. Fisk. Havunders 4:1-16.

[40]. Von Westernhagen, H. and H. Rosenthal. 1976. Some aspects of the suitability of various Philippine siganid species (Siganidae) for mariculture. J. Aqua. 9:297311 .

[41]. Wambiji, N., J. Ohtomi, B. Fulanda, E. Kimani, N. Kulundu, and Y. Md. Hossain. 2008. Morphometric relationship and condition factor of Siganus stellatus, S. canaliculatus and S. sutor (Pisces: Siganidae) from the Western Indian Ocean Waters. South Pac. Stud. 29(1): 1-15.

[42]. Wassef, E. A. and H. A. Abdul Hady. 1998. Breeding biology of rabbitfish Siganus canaliculatus (Siganidae) in mid Arabian Gulf. Fish. Res. 33(13):159-166.

[43]. Woodland, D. J. 1990. Revision of the fish family Siganidae with descriptions of two new species and comments on distribution and biology. Indo-Pacific Fishes (19):136.

[44]. Wu, R. S. 1984. The feeding habits of seven demersal fish species in a subtropical estuary. Asian Mar. Biol. 1:17-26. 